\title{
Microstructure investigation of premature corroded heat exchanger plates
}

\author{
Anna Wassilkowska, \\ Tadeusz Skowronek and \\ Stanisław Rybicki, Cracow, Poland
}

\section{Keywords}

Plate heat exchanger, stainless steel, grain boundaries, pitting, fretting corrosion

\begin{abstract}
A food processing plant supplied different heat exchanger plates to investigate the cause of their premature corrosion. In the elder version of the system, heat exchanger plates of grade 316/316L worked for five years before they became unsuitable for use. The new production line includes two heat exchangers working interchangeably to allow breaks for regular cleaning. An increased permeability during hydrogen test showed that corrosion of new plates started in one of the heat exchangers after two weeks, and in the second one after few months. Leaks manifested themselves by a regular pattern of corrosion pitting, occurring exactly in contact points of adjacent plates. A detailed study of the microstructure features of the austenitic steel plates was performed using scanning electron microscopy and metallography. It was found that plates corroding prematurely had surface impurities containing chlorides. A characteristic feature of the corrugated plate surface is secondary recrystallized microstructure with thick and pronounced austenite grain boundaries. Pitting was identified as the dominant material degradation mechanism promoted by fretting corrosion of adjoining plate ribs.
\end{abstract}

316/316L [2-4]. Under prescribed operation conditions and sludge cleaning, thin heat transfer plates should work without corrosion failure for a period above 3 years, which corresponds to the properties of those steels as a corrosion resistant material. Experience in domestic food processing plants has shown, that service life of standard stainless steel plates type 316/316L reaches normally about 10-12 years.

For leakage detection of industrial PHE, the hydrogen leak detector can be periodically used, e.g., after cleaning of fouling. As a tracer gas, a nitrogen hydrogen admixture containing 5-10 wt.- $\% \mathrm{H}_{2}$ is applied. The leak measure range is from 5 to $100 \mathrm{ppm}$ with a sensitivity of $0.5 \mathrm{ppm}$ hydrogen, equivalent to rates of $5 \times 10^{-7}$ mbar/s. An increase in hydrogen concentration above $10 \mathrm{ppm}$ during the measurement means that corrosion leaking starts, leading to plate failure.

Plates are usually corrugated for better thermal conductivity and mounted to- gether in the compact heat exchanger construction (see Figure 1) [5]. The number of plates and the heat exchanger size are calculated for optimal heat capacity. In such heat exchanger, fluids flow in opposite directions (one in odd and the other in even channels) and plate channels force the flow. For effective heat transfer characteristics (maximum turbulence) and for eliminating dead spots for inlet and outlet fluids, the plate corrugation design of the heat exchanger is essential [1]. Each plate makes a single barrier between fluids. The novel corrugation pattern serves to improve the strength and rigidity of the thin wall separating the two media [1]. It induces highly turbulent flow, however, the formation of deposits (fouling) is not always eliminated.

The present study aims to understand the cases of premature corrosion of heat transfer plates used in PHE for cooling in some food processing plants. There are two heat exchangers running interchangeably 


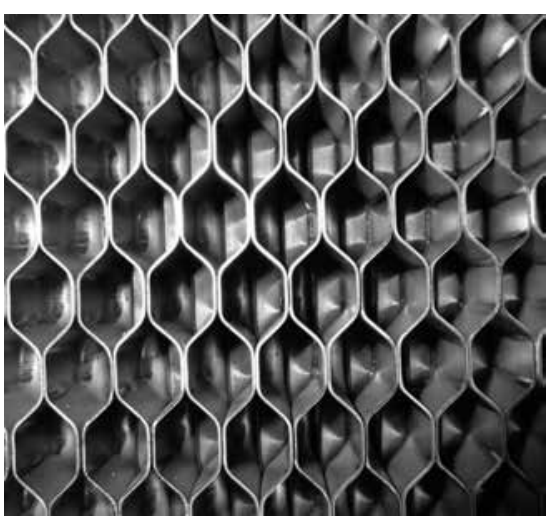

Figure 2: Outside view of an assembly of heat exchanger plates (batch D)

in one continuous production line. Such scheme enables alternate breaks for automatic plate cleaning. Due to the special guiding system (see Figure 1), plates are easily aligned during opening and closing the assembly (normal dismounting of PHE for exchange of gaskets every 3 years).

Both food processing plant heat exchangers had worked since 2008, but five years later all plates had to be exchanged for new because of their corrosion failure. However, only two weeks after the plates had been exchanged, the hydrogen permeability in one of the PHE was found to be $18 \mathrm{ppm}$. Some months later the second PHE showed leakages as well, whereas operation and cleaning conditions remained the same for both heat exchangers. For better understanding of the factors governing their rapid corrosion, selected heat transfer plates have been investigated microscopically.

\section{Material and experimental method}

Three groups of samples were used as objects of this study. The investigated plates have different corrugations depending on the type of PHE and the supplier. The samples were cut after visual examination of the heat exchanger design under working condition and after macroscopic analysis of the plates.

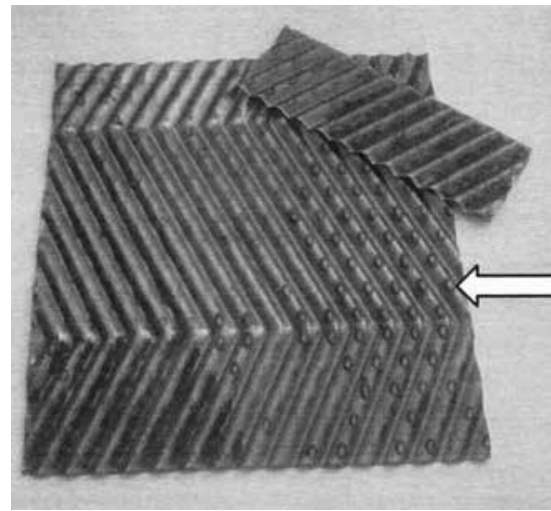

Figure 3: Specimen cut from a leaking heat exchanger plate (batch E), pitting shown with arrow

Batch (C) covers strips of material cut from the edge of assembled plates so as not to open the heat exchanger. Batch (D) comes from assembled plates with an increased permeability during hydrogen test (above $10 \mathrm{ppm}$ ), which, according to the manufacturer's instruction, must be removed from service (see Figure 2). This PHE was opened and it was found, that plates having worked only about $400 \mathrm{~h}$ showed pitting on the water circuit side. The electrochemically active surface area, i.e., the observed pattern of corrosion spots, corresponded exactly to the contact points of adjacent plates.

Batch (E) comes from a damaged plate, taken away during plate exchange in year 2008. It had worked for five years and was already unsuitable for use due to numerous corrosion pits (see Figure 3). Plates hang correctly when placed alternately, i.e., with chevron pointing downwards and chevron pointing upwards [1]. Basically, the leaking places are clearly manifested by regular pattern of burned spots in contact points of adjacent plates.

The stainless steel type of PHE plates was chemically analyzed by spark emission spectrometric method using the FoundryMaster (WAS) device. The minimum carbon content of the steel, which can be detected by this method, was 0.005 wt.- $\%$. The measurement must be performed on a flat surface of minimum area of $1 \times 1 \mathrm{~cm}$. This re-

\begin{tabular}{|c|c|c|c|c|c|c|c|c|}
\hline \multirow{2}{*}{ Specimen } & \multicolumn{7}{|c|}{ Chemical composition (wt.-\%) } \\
\cline { 2 - 10 } & $\mathrm{C}$ & $\mathrm{Cr}$ & $\mathrm{Ni}$ & $\mathrm{Mo}$ & $\mathrm{Si}$ & $\mathrm{Mn}$ & $\mathrm{P}$ & $\mathrm{S}$ \\
\hline 316 nom. & $<0.08$ & $16-18$ & $10-14$ & $2-3$ & $<0.75$ & $<2$ & $<0.045$ & $<0.03$ \\
\hline $\mathrm{C}$ & 0.11 & 16.5 & 9.97 & 2.00 & 0.43 & 0.89 & 0.014 & 0.005 \\
\hline $\mathrm{D}^{*}$ & 0.15 & 16.6 & 9.95 & 1.97 & - & 1.33 & 0.003 & - \\
\hline
\end{tabular}

*values are not accurate

Table 1: Results of the spark emission analysis of specimens $C$ and $D$

quirement qualified sample $\mathrm{C}$ only for testing. Therefore, the chemical composition was measured further by the use of nonstandardized method in a Hitachi S-3400N scanning electron microscope equipped with an EDS spectrometer from ThermoScientific. The composition was quantitatively examined only for elements of atomic number $Z>10$, i.e., without determining the light elements [6]. The characteristic X-rays are emitted from micrometer depth and the analysis of the chemical composition was done from single points inside austenite grains, as well as from surfaces of $100 \times 100$ $\mu \mathrm{m}$ at magnification of $\times 1000$.

By scanning electron microscopy (SEM), the topography of the plate surface was observed in a natural state - without cleaning or polishing. The place of observation was on the convex surface of the plates, where the friction and corrosion processes are maximal. Finally, the microstructure of the samples (C) and (D) was investigated using a metallographic microscope. Metallographic specimens were made using the method of Struers [7]. After mechanical polishing in aluminum suspension with particles of 0.1 $\mu \mathrm{m}$, the specimen surface was polished electrochemically in $10 \mathrm{wt} .-\%$ aqueous oxalic acid solution at a voltage of $15 \mathrm{~V}$ for $60 \mathrm{sec}$.

\section{Results and discussion}

The nominal chemical composition of the austenitic stainless steel 316, from which the plates of the heat exchanger are made, is as follows [4]: C $<0.08, \quad \mathrm{Cr}: 16-18$, Ni: $10-14, \quad M 0: 2-3, \quad S i<0.75, \quad M n<2$, $\mathrm{P}<0.045, \quad \mathrm{~S}<0.03, \quad \mathrm{~N}<0.1 \quad$ (wt.-\%). This chemical composition provides both high corrosion resistance of parts and equipment for the food and chemical industries and the high plasticity, required for their deep drawing. Steel grade 316 is corrosion resistant in atmospheric environment, natural water, alkaline solutions and certain organic and inorganic acids. The molybdenum content makes it resistant to corrosion in an environment containing chloride ions.

The chemical composition of the measured samples is shown in Table 1. The nominal composition of the steel 316 is shown for comparison. Due to the small size of sample D, the values obtained are not accurate. Sample E had no flat area of size $1 \mathrm{~cm}^{2}$, so its composition could not been determined.

The analysis of Table 1 shows that the carbon content in both samples $\mathrm{C}$ and $\mathrm{D}$ is higher than the nominal value for this steel. It is known that the carbon content in 

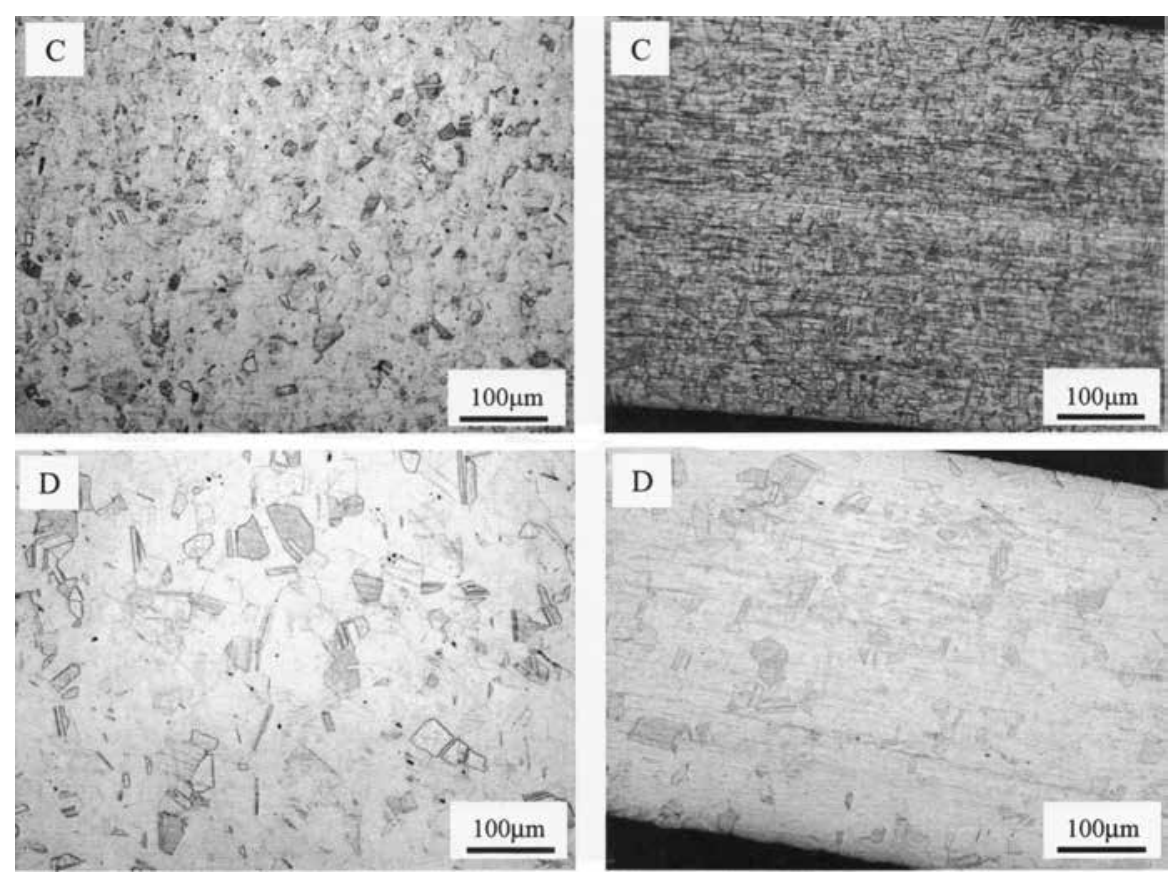

Figure 4: Light microscopy of metallographic specimens: plane section (left) and transverse section (right)
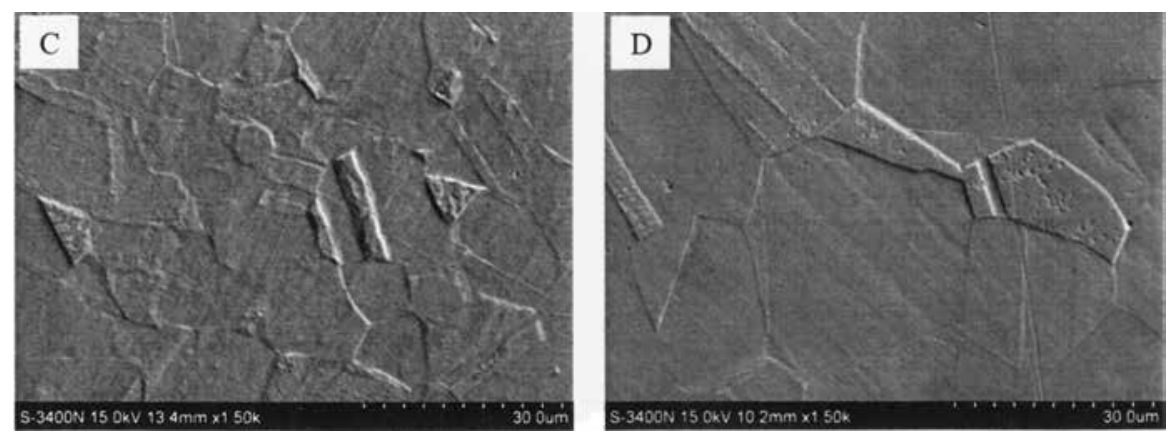

Figure 5: SEM images of plane section (etched) metallographic specimens

\begin{tabular}{|c|c|c|c|c|}
\hline Result & \multicolumn{4}{|c|}{ Chemical composition (wt.-\%) } \\
\hline & $\mathrm{Cr}$ & $\mathrm{Ni}$ & $\mathrm{M} 0$ & $\mathrm{Si}$ \\
\hline C1 & 17.0 & 9.8 & 0.9 & 0.5 \\
\hline C2 & 17.3 & 10.2 & 1.8 & 0.7 \\
\hline C3 & 17.2 & 9.8 & 1.7 & 0.6 \\
\hline D1 & 16.6 & 9.8 & 0.9 & 0.5 \\
\hline D2 & 17.3 & 10.2 & 1.7 & 0.7 \\
\hline D3 & 16.8 & 9.9 & 1.6 & 0.5 \\
\hline E1 & 16.1 & 8.7 & 1.9 & 0.5 \\
\hline E2 & 17.3 & 10.8 & 2.0 & 0.7 \\
\hline E3 & 16.7 & 9.9 & 2.0 & 0.7 \\
\hline
\end{tabular}

Table 2: Results of the EDS analysis of specimens $C, D$ and $E ; 1$ - minimal values, 2 - maximal values, 3 - element concentration in area of $100 \times 100 \mu \mathrm{m}$ austenitic steels, which the profiled plates are made of, influences significantly their corrosion resistance and especially affects their susceptibility to cold deformation. Moreover, in order to prevent intergranular corrosion, austenitic steels must contain less than 0.03 wt.- $\%$ C and certain quantities of titanium, molybdenum or niobium. The measured content of the main alloying elements $\mathrm{Cr}$, Ni and Mo was in the lower range of nominal values.

The comparative analysis of the material $\mathrm{C}$ and D shows that the size of austenitic grains of specimen D is larger (see Figures 4 and 5). A reason for this is probably a smaller degree of plastic deformation in those plates which have different profiling. It is known that the low degree of plastic deformation (from 3 to $8 \%$, also called "critical") leads to an intensive growth of austenitic grains after recrystallization [8].

More detailed examination of the contents of the elements (even in different grains, see Figure 5) is summarized in Table 2. The measurement was made in ten grains, but only the highest and lowest values for each of the main elements are shown here. It is not possible to characterize the peaks of characteristic X-ray emission from trace elements phosphorus and sulfur (which overlaps with the line of Mo) and from manganese (which overlaps with the line of $\mathrm{Cr}$ ) [6].

Comparing the received values for the chemical composition of samples in $\mathrm{Ta}-$ bles 1 and 2, one can notice, that there are some differences in amounts of $\mathrm{Cr}, \mathrm{Ni}$ and Mo. According to the spark emission method, concentrations of molybdenum in samples C and D are almost 2 wt.-\%, while in the EDS analysis, they are 1.7 and 1.6 wt.-\%, respectively. This difference could be due to the fact that samples for the spark method did not have perfectly flat surfaces. But the values obtained for the element Mo were considerably lower than the nominal of 2-3 wt.-\% suggesting that grain boundary corrosion could occur in these samples during the operation.

Figure 6 shows the areas of natural convex surface of investigated plates, where the degree of plastic deformation is the largest. When studied under small magnification, an "orange peel" structure was found on the surface of material C, similar to the one referred to for steel grade 304 in [9]. According to [9], the cause of the characteristic surface shape of the deep drawn plates may be one of the following:

1. Upon plastic deformation of austenitic class steels, a partial transformation of 
austenite into martensite occurs. Formed martensitic phase has a high density of dislocations and is located inside the defective areas of austenite.

2. The percentage of nickel in the alloy is lower than the nominal one (about 9 wt.-\%). The higher nickel content improves the properties of the steel for deep drawing.

3. The growth of the grains after the recrystallization is carried out more easily in the direction of the surface and a portion of the grains protrude above the surface.

On the surface of sample D, many black particles can be seen, mostly uniformly distributed (see Figure 6). They may affect premature corrosion because they are seen only on steel D, therefore an attempt to identify them was made. The EDS spectral analysis of those particles showed that they contain chlorine, sodium and potassium. The presence of these elements in the circulation of cooling water was not expected. However, spectral analysis demonstrated that such elements are present (see Figure 7). These elements could be some particles of salts or solids, but unfortunately, their nature is not clearly established.

Execution of ribbings certainly has an impact on the plate service life. Protrusions or indentations are particularly vulnerable to temperature gradients and water hammer at points of material contract. A detailed SEM analysis of embossing convex zone clearly shows an intergranular structure (see Figure 6). Material $\mathrm{C}$ has pronounced grain boundaries which, in the prematurely corroded samples D, are even thicker and deeply indented. The large grain size distribution of both stainless steels could be related to the ongoing recrystallization processes of post-cold plastic deformation. Immediately after recrystallization, the structure consists generally of differently oriented small grains, but due to the significant grain separation surface, the system is in unbalanced energy state [8]. Therefore, the prolonged storage or operation proceedings lead to the growth of individual grains at the expense of the smaller. Obtained structure consists of large individual grains surrounded by small grains. Grains in sample D are also of different sizes, but without surface relief, apparently because of the different degree of cold deformation.

An important aspect of the specimen surface topography is the question: is this already intercrystalline corrosion? The study of plate E shows that the structure of the grains near the corroded places where the plates touch at work, is practically similar (see Figure 6).

Despite the so undermined structure boundaries, the turbulence flow between the heat exchanger plates cannot cause erosion or flow-assisted metal loss. Erosion is a process of mechanical abrasion of protecting film by particles suspended in fast flowing liquid. It is often manifested as a craterlike wear on the surface, but this was not the case observed in the present study. Stainless steels do not suffer from flow-assisted corrosion where a protective oxide
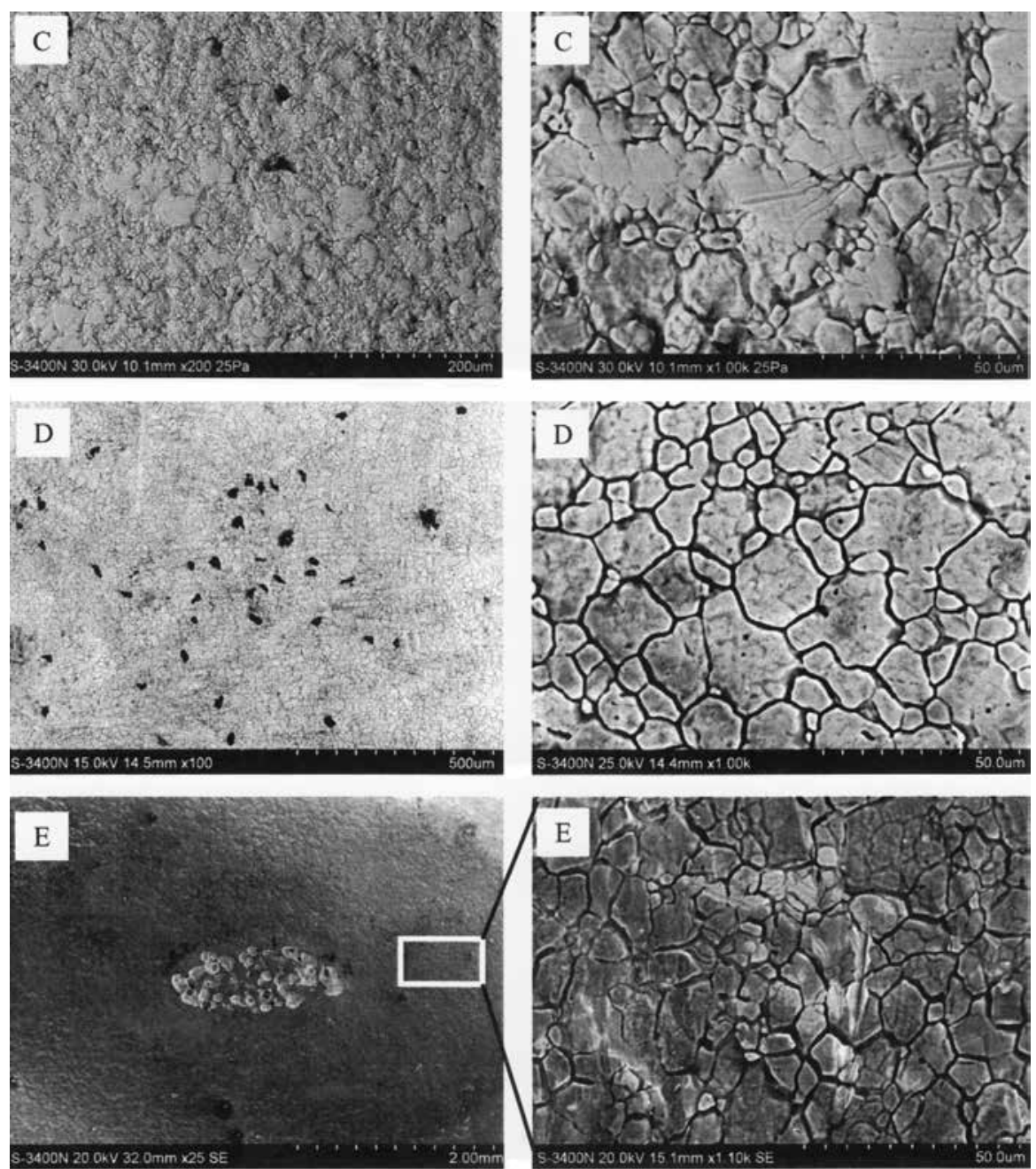

Figure 6: SEM images of surface microstructure; $C$ - the "new" plate, $D$ - plate corrosion starts after 400 h of service, E - leaking plate taken off from PHE (end of service life)

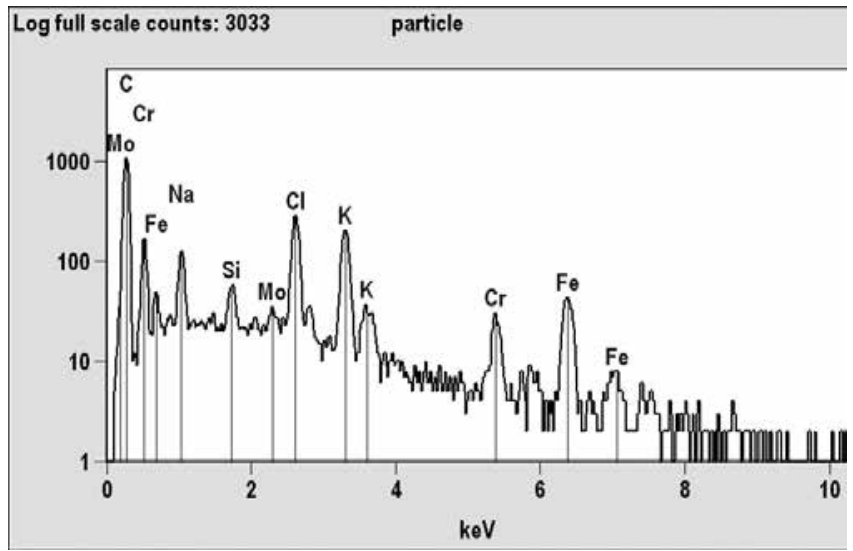

Figure 7: EDS spectrum of dark particles on the surface of material $(D)$ 


\begin{tabular}{|c|c|}
\hline Type & Description \\
\hline Pitting & $\begin{array}{c}\text { The appearance of extremely localized corrosion spots, in an otherwise passive surface, is very typical for stainless steels } \\
\text { PHE. It is an autocatalytic process that starts as very small holes damaging the deep structures of the metal. The driving } \\
\text { power of localized galvanic corrosion is the depassivation of a small area which becomes the anode for another potentially } \\
\text { huge area. Stagnant water conditions and chlorides favor pitting. }\end{array}$ \\
\hline Fretting & $\begin{array}{c}\text { Fretting is a wear process caused by abrasive action at the contact area between two solids subjected to relative sliding mo- } \\
\text { tion. Soft materials often exhibit higher susceptibility to fretting (its amplitude can be as low as } 3 \text { to } 4 \text { nm [10]). The mechani- } \\
\text { cal wear is often followed by oxidation of the freshly exposed metallic surfaces. The oxidized debris often acts as an abrasive } \\
\text { agent that increases the rate of fretting. It increases the surface roughness and promotes corrosion pits, thus decreases the } \\
\text { fatigue strength and can initiate fatigue cracks in the fretting zone. }\end{array}$ \\
\hline Intergranular & $\begin{array}{c}\text { It is considered to be caused by the segregation of impurities at the grain boundaries or by enrichment or depletion } \\
\text { (e.g., selective leaching) of one of the alloying elements in the grain boundary areas. Stainless steel can experience intergran- } \\
\text { ular corrosion in the case of the formation of chromium carbide at the grain boundaries during an improper heat treatment. } \\
\text { Thus, the boundaries of crystallites of the material are more susceptible to corrosion than their insides. }\end{array}$ \\
\hline
\end{tabular}

Table 3: Main types of corrosion in stainless steel plate heat exchangers investigated

layer dissolves in a fast flowing water, either, so the underlying metal corrodes to recreate the surface oxide. It is harmful for the material that the local pits penetrate the surface and material properties change.

Table 3 lists the main types of corrosion found for investigated heat transfer plates. Metastable pits exist even when the stainless steel is passive and may cause shorttime burst of release material, before the surface film is passivated again (becomes dormant) [11].

The surface topography most probably influences the degree of pitting. The pits propagate into fully developed propagating pits. At the very contact of the plate ribs, where friction takes place by small oscillations, there were typical scratches testifying the fretting corrosion (see Table 3). The electrochemically active area is significantly larger for freshly abraded surface [11]. Thus, for the protection of the whole system against water hammer, it is important that start-ups and close-downs of the heat exchanger are carried out with great care [1].

\section{Conclusions}

The study carried out on material from three different batches of heat exchanger plates used in the production line for beer, showed that:

1. All investigated plates C, D and E, according to the manufacturer, are made of stainless austenitic steel 316/316L. However, the content of carbon in samples C and D has been increased (reached $0.11 \mathrm{wt} . \%$ ) and the content of molybdenum is $1.6-1.7 \mathrm{wt} .-\%$, less than the nominal value of 2-3\%. However, all the samples examined exhibit austenitic structure.
2. Following the recrystallization processes that occur after cold plastic deformation of the corrugated plates, the structure of plates C consists of large grains surrounded by many small ones. This is the effect of "orange skin" and separate grain boundaries can be clearly observed.

3. The plates $\mathrm{D}$, in which premature corrosion was established by the method of hydrogen permeability, have a coarse austenitic structure characterized by thickened boundaries of the grains. Therefore, the low corrosion resistance of steel D is simultaneously influenced by two factors:

- the clear-cut intercrystalline corrosion due to the lower content of Mo, and higher content of carbon

- the critical level of deformation changes, reached in the profile of the ribs

Moreover, these plates are contaminated with compounds of chlorine, sodium and potassium of unknown origin

4. Plates E that had worked a long time up to their life limit, indicate destruction caused by fretting corrosion of adjoining ribs.

Environmental factors could be examined parallel to the materials microstructure characteristics [12]. To prevent the fretting corrosion (the most destructive corrosion mechanism of investigated plates) in the design of the stainless steel PHEs, one should consider the compensation of thermal expansion and avoidance of water hammer.

\section{References}

1 AlfaLaval - Plate technology - Heat exchangers: Optimizing the use of heat energy, http://local.alfalaval.com/ko-kr/keytechnologies/heat-transfer/Documents/ Alfa\%20Laval\%20-\%20plate\%20technology.pdf (21.07.2015)
2 DIN EN 10088-1: Stainless steels - Part 1: List of stainless steels, Beuth, Berlin, Germany (2014)

3 E. Partington: Stainless Steel in the Food and Beverage Industry, Materials and Application Series, Vol. 7, Euro Inox (2006) http://www.euro-inox.org/pdf/map/StSt_in FoodandBeverage_EN.pdf (21.07.2015)

4 N. N.: Outokumpu High Performance Stainless: Type 316/316L, A molybdenum-containing austenitic stainless steel with improved resistance to chlorides relative to Type 304/304L stainless steel, http://www.outokumpu.com/ SiteCollectionDocuments/Datasheet-316-316Limperial-hpsa-outokumpu-en-americas.pdf (21.07.2015)

5 T. Dzierżawski: Gazownictwo i ciepłownictwo, Wydawnictwo Szkolne i Pedagogiczne, Warszawa, Poland (1996)

6 A. Wassilkowska, A. Czaplicka-Kotas, M. Zielina, A. Bielski: An analysis of microarea chemical composition using EDS technique, Technical Transactions 1 - Ch (2014), pp. 133-148

7 N. N.: Struers Application Notes: Metallographic preparation of stainless steels, http://www.struers.com/resources/elements/12/101820/Application\%20Notes\%20 Stainless\%20Steel\%20English.pdf (21.07.2015)

8 A. P. Gulyaev: Metallovedenie, Metallurgia, $6^{\text {th }}$ Ed., Moscow, Russia (1986)

9 G. Kurtev: Examination of the surface roughness of a part from austenitic stainless steel after deep drawing, Scientific Materials of Technical University Ruse 52 (2013), pp. 106-110, http://conf.uni-ruse.bg/bg/docs/ cp13/11/11-20.pdf (21.07.2015)

10 ASM Handbook, Vol. 13A, Corrosion: Fundamentals, Testing and Protection, ASM International, 1987

11 G. Hertig: Bioaccessibility of Stainless Steels Importance of Bulk and Surface Features, Doctoral Thesis, Royal University of Technology Stockholm, Sweden (2008)

12 K. M. Deen, M. A. Virk, C. I. Haque, E. Ahmad, I. H. Khan: Failure investigations of heat exchanger plates due to pitting corrosion, Engineering Failure Analysis 17 (2010), pp. 886-893 DOI:10.1016/j.engfailanal.2009.10.023 


\section{Bibliography}

DOI $10.3139 / 120.110837$

Materials Testing

58 (2016) 3, pages 218-223

(C) Carl Hanser Verlag GmbH \& Co. KG

ISSN 0025-5300

\section{The authors of this contribution}

Dr.-Eng. Anna Wassilkowska is a specialist in electron microscopy at the Faculty of Environmental Engineering, Cracow University of Technology (CUT), Poland. She received her PhD in Engineering Science from AGH University of Science and Technology, Cracow, Poland in 1998. Since 2000, she was a visiting researcher in the following institutes in Germany: Forschungszentrum Jülich, MPI of Microstructure Physics Halle and Technical University Munich. Her research team received the Sawamura Award for distinguished paper in ISIJ International in 2006. Now she is working on microstructure characterization, on mechanical behavior of environmental and engineering materials as well as on corrosion topics.

Dr.-Eng. Tadeusz Skowronek, born in 1952, received his MSc in Metallurgy and Metal Physics from AGH University of Science and Technology, Cracow, Poland in 1979 and $\mathrm{PhD}$ in the field of special steels and alloys from the Faculty of Metals Engineering and Industrial Computer Science at the same university in 2006. Since 2006, he is a senior lecturer in the Department of Physical and Powder Metallurgy, AGH, Cracow, Poland. His research interests include metal science and quantitative metallography.

Dr.-Eng. Stanislaw M. Rybicki, born in 1958 , graduated from Cracow University of Technology (CUT), Poland in 1983. He earned his PhD in Environmental Engineering at the same university in 1996. He is a licensed construction engineer with over 30 years of experience in water and wastewater treatment process design. He completed several research grants in the field of water and wastewater treatment, mostly on interaction between processes and nutrient removal and recovery. He is currently Assistant Professor at CUT.

\section{Abstract}

Gefügeuntersuchung von vorzeitig korrodierten Wärmetauscherplatten. Eine Lebensmittelverarbeitungsfabrik legte zur Untersuchung verschiedene Wärmetauscherplatten vor, um die Ursache der vorzeitigen Korrosion zu ermitteln. In der älteren Version desselben Systems waren Wärmetauscherplatten aus dem Stahl des Types 316/316L für fünf Jahre eingesetzt, bevor sie für eine weitere Verwendung unbrauchbar wurden. Die neue Produktionslinie enthält zwei Wärmetauscher die abwechselnd betrieben werden, um Unterbrechungen für die regelmäßige Reinigung zuzulassen. Eine erhöhte Permeabilität in entsprechenden Wasserstoffversuchen zeigte, dass die Korrosion der neuen Platten in einem der beiden Wärmetauscher bereits nach zwei Wochen und im anderen nach ein paar Monaten einsetzte. Die undichten Stellen wiesen eine reguläre Streuung von Korrosionslöchern (Pittings) auf, die exakt dort auftraten, wo die Kontaktstellen zu den benachbarten Platten waren. Es wurde eine detaillierte Studie der Mikrostruktur der austenitischen Stahlplatten mittels Rasterelektronenmikroskopie und Metallographie durchgeführt. Es wurde herausgefunden, dass die vorzeitig korrodierten Platten Oberflächenverunreinigungen aufwiesen, die Chloride enthielten. Ein charakteristisches Merkmal der geriffelten Platten besteht in der sekundär-rekristallisierten Mikrostruktur mit dicken und ausgeprägten austenitischen Korngrenzen. Lochkorrosion (Pitting) wurde als dominanter Degradationsmechanismus identifiziert, unterstützt durch Fraßkorrosion der verbundenen Plattenrippen. 